\title{
USEFUL FLORA GROWN AND TRADED IN RECIFE, BRAZIL
}

\author{
ISABEL MARIA MADALENO \\ Institute of Geography and Spatial Planning (IGOT), Universidade de Lisboa, Portugal
}

\begin{abstract}
Recife is a coastal city located in Brazil. The Atlantic seashores were occupied in the beginning of the 16th century by the Portuguese, in search for Brazil-wood first and sugarcane, later, both very precious for Europe. After the Dutch conquered the now state of Pernambuco, in 1630, local population came down the hills of Olinda to settle close to the rivers Capibaribe and Beberibe, where a new urban agglomerate grew, named Recife, the Portuguese word for reef. This Brazilian Venice, known for its water channels and greenery, now has a million and a half residents and still proudly displays the tall coconut trees that impressed the early European colonisers. Coconuts are the first ranking species consumed in Recife, as the survey conducted in late 2019 and early 2020 proved. Research follows the methodology used in previous studies: (1) examination of 16th and 17th century manuscripts; and (2) in-depth interviews to local fruit, spice, and medicinal plant traders (47) and to urban gardeners (3). Results from the 50 testimonies show that about 192 native and exotic species are grown and traded in Recife, $46.9 \%$ of which are consumed as food, about $43.8 \%$ as medicines, $8.8 \%$ as spices and $0.5 \%$ had other uses. The first objective of this contribution is to further feed the database gathered for two decades about Latin American flora, the second one is to explain the urban growth of Recife, in Brazil, and the third is to compare old and current usages, of the same plant species.
\end{abstract}

Keywords: Recife, Brazil, coast, flora, spices, medicines, food.

\section{INTRODUCTION}

Urban growth provoked natural capital loss, through times. According to McDonald et al. [1], urban expansion into natural habitat will destroy about $290,000 \mathrm{~km}^{2}$, an area larger than the entire UK, resulting from the direct impacts forecasted for the period 2000-2030. Brazil is, together with the USA, Nigeria and China, one among four of the most affected countries in the world, by urban agglomeration expansion and subsequent biodiversity loss. Anthropogenic damage to the natural habitats includes climate change effects on the number of wild aromatic and medicinal plant species, claiming for further efforts to mitigate the consequences of biodiversity destruction and the preservation of traditional medicinal knowledge, particularly in developing countries [2].

As da Costa and Motta wrote: "Modern lifestyle has resulted in a gradual dismantling of the vital services offered by nature, putting human existence at risk" [3]. This contribution is part of a project aimed at answering the question: Was flora consumption sustainable in Recife, from the beginning of Portuguese colonisation to our days? In order to find responses the methodological approach was threefold, starting with the examination of three 16th and 17 th century manuscripts, as well as two printed book collections, followed by a scientific mission to the urban agglomeration, aimed at conducting a survey to useful flora consumption in our days, intended to evaluate the sustainability of native American plant species through times. Cross examination of data gathered will be the last phase of our methodology. The structure of the paper, after this introduction, plus the geographical location, objectives definition and methodology, will include the discussion of the results gathered in the city of Recife, the capital of Pernambuco State, illustrated with tables and photos, as well as the evolution of the crops and vegetation mentioned in literature, towards a conclusion. 


\section{GEOGRAPHICAL LOCATION}

Located on the Atlantic coast of Brazil, at $8^{\circ} 3^{\prime} 15^{\prime \prime}$ south of the Equator and $34^{\circ} 55^{\prime} 00^{\prime \prime}$ west of Greenwich, Recife has on average 7 metres of altitude above sea level. The municipality accounted for $1,537,704$ inhabitants in 2010 , the last census. It is $1,878 \mathrm{~km}$ distant from Rio de Janeiro, located southwards [4]. It is a tropical environment that registers $25.8^{\circ} \mathrm{C}$ on average, per annum, and a total rainfall of $1,804 \mathrm{~mm}$ [5]. Brazil is independent from Portugal, from 1822 onwards, and the country is one of the richest on biodiversity. The state of Pernambuco, located in the north-eastern area of Brazil, is dominated by Atlantic Forests (Mata Atlâtica) alongside the seashores and by arid and semiarid environments, in the interior areas. The city of Recife is drained by rivers and channels that gave it the tag of Brazilian Venice. Portuguese colonisation started on the hills of Olinda, located north of Recife (Fig. 1), which foundation dates from the 12 March 1537 [6].

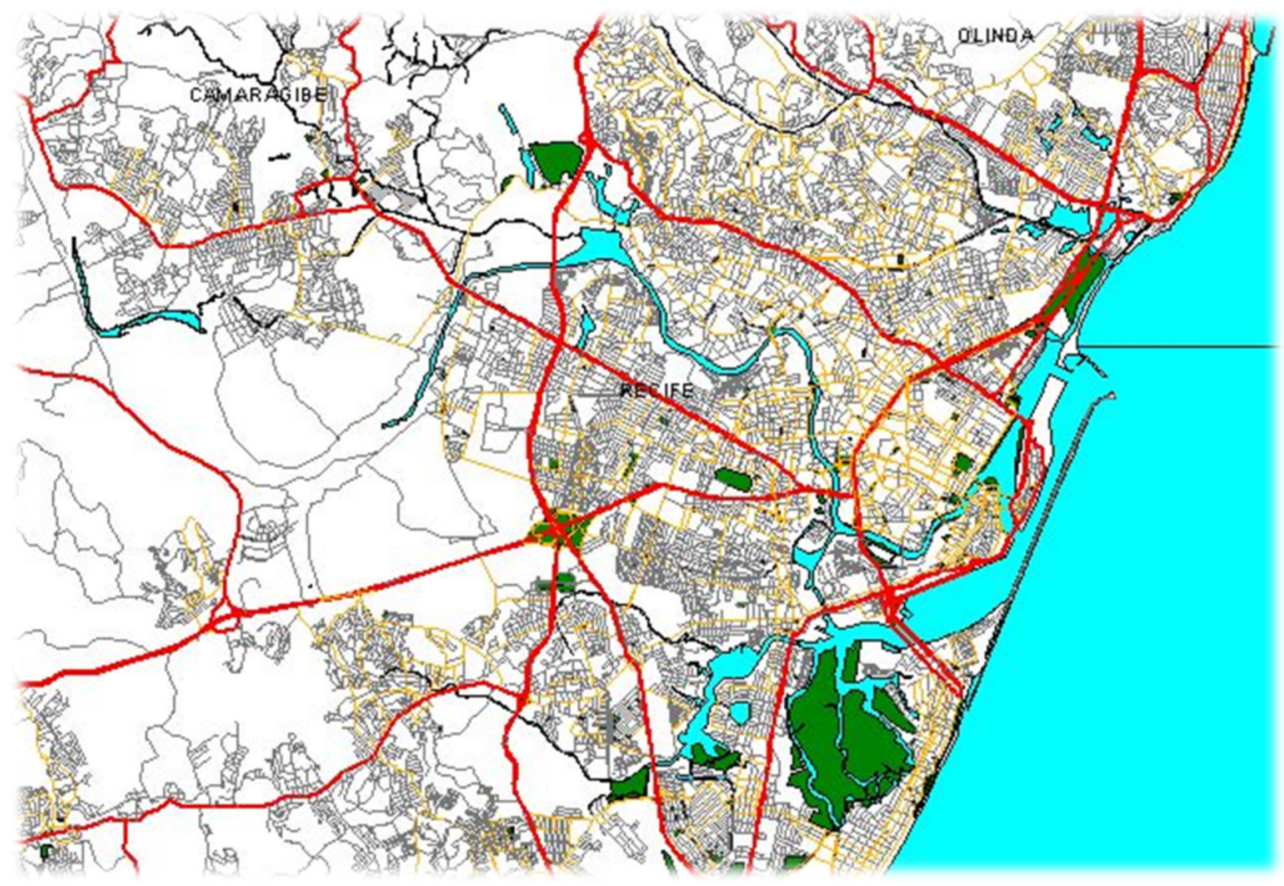

Figure 1: The Brazilian Venice - Recife, capital of Pernambuco State, Brazil. (Source: www.mbi.com.br/mbi/loja/geoprocessamento/mapa-digital-municipiospernambuco- $d d d-81 /$.)

\section{OBJECTIVES AND METHODOLOGY}

The food, spices and medicines growth and trade project focusing Latin American countries, currently developed in the University of Lisbon, has three main aims: (1) To contribute with new information to the database gathered for over two decades about the useful Latin American flora, seen as the vegetable species that are part of local diets or then applied to heal mild and chronic diseases, as well as flora that has cosmetic usages; (2) To explain the urban growth of Recife, in Brazil, as urbanisation of Pernambuco began with Olinda, the 16th century Portuguese settlement, and continued with Recife, founded by the Dutch, in 1630; 
and (3) To compare 16th and 17th century uses of flora, as can be read in old manuscripts, with the current applications. Because some of the plant species in consumption today were already grown, in the beginning of European colonisation, a third objective will be to cross-reference data gathered in manuscript examination and during the 2019/2020 survey in Recife.

Methodology was based on the analysis of primary and secondary data gathered. Starting with this last set of information, it consisted on reading manuscripts, three of them from archives and one printed material dating from the 16th century: (1) A digitalised version of a chronicle written in 1558, about the Kingdom of D. Manuel I of Portugal by de Goes [7]; (2) A digitised version, again by The Portuguese National Library, of the ten chronicles (1552-1561) written about Portuguese discoveries, authored by de Castanheda [8]; (3) A manuscript with several José de Anchieta writings gathered by Jesuit priests and examined in the Archives of The Vatican City, in 2014 [9]; and (4) Another secondary source of information about this 16th century author was read, in printed format, in the Library of John Paul the second, in the Catholic University, in Lisbon [10].

Last, but not least, we examined the thirty volumes printed in 2013-2014 by Círculo de Leitores Editors, in Lisbon, containing all the writings authored by António Vieira, a 17th century Jesuit priest. Vieira lived in Brazil and travelled throughout actual Pernambuco state, as he mentions Olinda in his writings [11]. After and during the process of reading these long manuscripts and printed material, we systematised all data about flora consumptions and other usages in comparable tables, making easier the process of botanical identification of species and interpretation of data. The Missouri Botanical Garden website was preferred, as far as the scientific classification of Latin American flora is concerned [12].

There was a second phase in the methodological process, following manuscripts and printed material examination: Investigation of the current uses of flora in Recife, Brazil, conducted during a scientific mission, in the end of the year 2019 and beginning of 2020, aimed at gathering in-depth interviews to two categories of informants: (i) fruit, roots, fresh vegetables, staples, spices, and medicinal plant traders, found in markets and along the streets (47 informants); and testimonies of three urban gardeners (3), from neighbourhoods such as Boa Viagem and S. José. The survey totalled 50 respondents. The botanical identification of the flora collected during fieldwork, was the following procedure, so as to permit the crossexamination of data, both through times and across the world. After this final phase, primary and secondary information about the useful flora grown and traded in Recife will be analysed in the next pages.

\section{RESULTS AND DISCUSSION}

Results from the 50 interviews show that about 192 native and exotic species are grown and traded in Recife, $46.9 \%$ of which are consumed as food, about $43.8 \%$ as medicines, $8.8 \%$ as spices and $0.5 \%$ had other uses. Some of these species were already consumed in the early days of colonisation, as the manuscripts examination proved, because about $23 \%$ of the flora in consumption today was grown in this coastal location in those times. The trade of food, spices and medicines is a vital economic activity in any city, and native spices and fruits are much valued in local cuisine and consumed as part of Recife's culture. Examples are chilli with cachaça (an alcoholic drink made from sugarcane) or guava with cachaça. Why is sugarcane so important in Recife? The plantations of Saccharum were spread all over NorthEastern Brazil, as can be read in 17th century Vieira writings [11], because they soon replaced the first economic cycle of Brazilian economy, based on Brazil-wood recollection. This tree has a typical red bark, very appreciated in Europe, in the early years of colonisation. 
Research conducted in Recife, collected 84 species with medicinal uses, for mild affections, such as cough, flu, stomach or bowels indispositions. Cosmetic applications, to the hair and skin were also included in this category of usages. Yet, Protium heptaphyllum resin no longer pastes women's hair, as it did in the 16th century, because they don't use feathers as the early Indians did. But the consumption of local food species like cará (Fig. 4), is the same in our days as it was in de Anchieta's time [9], [10]. We will analyse flora used as food, first, then the top-ranking spices, to finalise with the healing and cosmetic species. The photos will illustrate the most important ones, and the tables will give information about its evidence in the old manuscripts, and the importance of current uses, as found during fieldwork. The detailed maps (Figs 2 and 3) show the two neighbourhoods where interviews to urban gardeners were conducted. They are easily spotted in map 1, respectively southwards and northwards of the port of Recife.

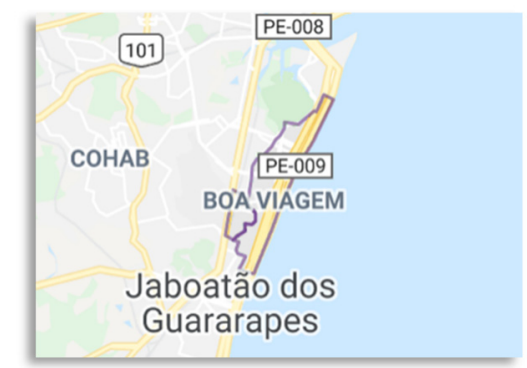

Figure 2: Detail of Boa Viagem neighbourhood. (Source: www.google.com.)

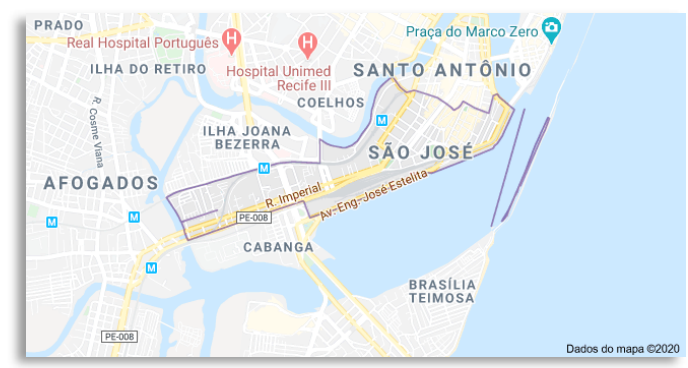

Figure 3: Detail of S. José neighbourhood. (Source: www.google.com.)

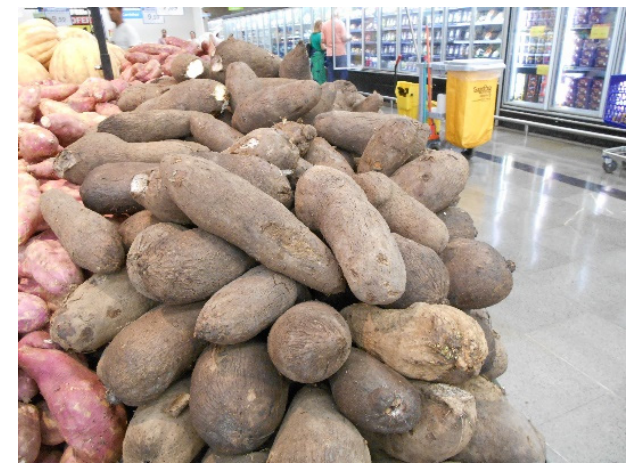

Figure 4: Cará, local staple food already consumed in the 16th century. (Source: Author's photo, 2020.)

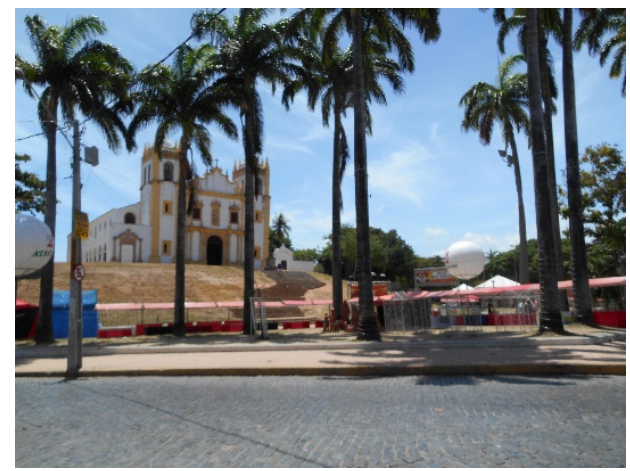

Figure 5: Coconut trees from Olinda, the first Portuguese settlement in Pernambuco State. (Source: Author's photo, 2019.) 


\subsection{The top-ranking food species consumed in Recife, in the old days and today}

The first ranking food eaten in Recife is coconut, with 30 occurrences, registered during the 2019/2020 University of Lisbon survey. Coconut palm trees dominated both the hills of Olinda (Fig. 5), and the sunny beaches, as the 16th and 17th century manuscripts reported [9]-[11]. Coconut water is consumed on the beach, in our times, because of its refreshing effects. However, this water is very healthy either, recommended against kidney stones and for helping to clean the digestive tract [13].

The second ranking food species found in Recife is native cashew, with 19 occurrences, a nutraceutical nut consumed salty or spicy, and sweet, with sesame and sugar, a delicacy. The fruit is also eaten in refreshing drinks, used to cure diarrhoea. In the 16th century, the fruit was fermented into an alcoholic drink, called cauim, by the Indians. We found no evidence of this consumption today in Recife, yet in a 2013 scientific mission to Kochi, Kerala, in India, the drink as the fruit tree were in usage, imported from Brazil in the early years of Portuguese colonisation [14].

Bananas were the third ranking fruit recorded in Recife, with eighteen occurrences (Table 1). They are amongst the healthiest foods, "rich in potassium, vitamin B6 and folic acid" [13, p. 30]. Bananas are adequate mood regulators, they lower blood pressure, have anti-diarrhoeal effects, and proven activity against nausea, insomnia and fatigue. Mangoes follow suit, in this instance imported from India (14 records). Passion fruits go next, a local nutraceutical, meaning a food that heals, with anti-depressive effects.

Another native American species, with 12 occurrences in the survey, was the pineapple. Jesuit priest Anchieta informed us, in his 16th century manuscripts that pineapples smelled very well, they were quite juicy and had excellent activity as kidney stone breakers. This fruit was named smelly-smelly (cheira-cheira) in Tupi, the local Indian idiom, and the given name was naná. We emphasise that cocoa has nine occurrences; another native American, the cocoa extracted from the tree has beneficial effects in cardiovascular diseases and regular consumption of chocolate reduces the risk of Alzheimer [15]. The same is valid for apples (11 records), and for grapes (9), as their consumption reduces the oxidative stress associated to aging. Apples prevent constipation, gout, and diarrhoea [13]. Father António Vieira didn't cope without apples, when he was sick, in Portugal [11].

Regarding staple foods, cassava registered 13 occurrences. One of four basic native American species, cassava was quoted by all the manuscript writers selected for this contribution. de Goes wrote in 1558: "They eat bread made of white roots, as big as carrots. (...) After being dried, the roots were turned into flour" [7, p. 80]. Sweet potatoes registered nine occurrences in the 2019/2020 survey. Corn came next, with seven records, and it was again mentioned in all manuscripts. The Portuguese traveller de Castanheda wrote this grain existed already when Pedro Álvares Cabral first discovered Brazil, in 1500 [8]. Father Anchieta not only refers to corn and cassava, but also to potatoes, the fourth native American staple food. The survey recorded four occurrences in supermarkets. The other local food mentioned by this Jesuit was cará (Dioscorea dodecaneura), as said, a root boiled or roasted and eaten instead of bread, the same usage it has in modernity.

Returning to the fruits consumed in Recife, several Rutaceae fruits, such as oranges and lemons are top-ranking preferences in Recife. The consumption of vitamin $\mathrm{C}$ is the best defence against free radicals, it helps alleviate inflammatory conditions like asthma, osteoarthritis and it boosts the immune system [13]. Regular consumption of oranges and lemon juice also prevents Alzheimer disease [15]. Guavas are native fruits, and they were mentioned by the Jesuit Vieira in his many writings. In Recife they are food and they like them preserved in cachaça. Guava jams are common at any table, even in hotel restaurants. 
Table 1: Top-ranking food species traded and grown in Recife, in the 16th and 17th centuries and today. (Source: Author, 2020.)

\begin{tabular}{|c|c|c|c|}
\hline $\begin{array}{l}\text { Common names } \\
\text { (in English) }\end{array}$ & Botanical names & $\begin{array}{c}\text { Occurrences } \\
(\mathrm{n} .)\end{array}$ & $\begin{array}{c}\text { Manuscripts } \\
\text { mentioned }\end{array}$ \\
\hline $\begin{array}{l}\text { Coco } \\
\text { Coconut }\end{array}$ & $\begin{array}{l}\text { Cocos nucifera } \mathrm{L} . \\
\text { ARECACEAE }\end{array}$ & 30 & {$[9]-[11]$} \\
\hline $\begin{array}{l}\text { Cajú } \\
\text { Cashew }\end{array}$ & $\begin{array}{l}\text { Anacardium occidentale L. } \\
\text { ANACARDIACEAE }\end{array}$ & 19 & [9], [10] \\
\hline $\begin{array}{l}\text { Banana } \\
\text { Banana }\end{array}$ & $\begin{array}{l}\text { Musa paradisiaca } \mathrm{L} . \\
\text { MUSACEAE }\end{array}$ & 18 & - \\
\hline $\begin{array}{l}\text { Manga } \\
\text { Mango }\end{array}$ & $\begin{array}{l}\text { Mangifera indica } \mathrm{L} \text {. } \\
\text { ANACARDIACEAE }\end{array}$ & 14 & - \\
\hline $\begin{array}{l}\text { Maracujá } \\
\text { Passion Fruit }\end{array}$ & $\begin{array}{l}\text { Passiflora edulis Sims } \\
\text { PASSIFLORACEAE }\end{array}$ & 13 & - \\
\hline $\begin{array}{l}\text { Mandioca } \\
\text { Cassava }\end{array}$ & $\begin{array}{l}\text { Manihot esculenta Crantz } \\
\text { EUPHORBIACEAE }\end{array}$ & 13 & {$[7]-[11]$} \\
\hline $\begin{array}{l}\text { Abacaxi } \\
\text { Pineapple }\end{array}$ & $\begin{array}{l}\text { Ananas comosus (L.) Merr. } \\
\text { BROMELIACEAE }\end{array}$ & 12 & {$[9],[10]$} \\
\hline $\begin{array}{l}\text { Maçã } \\
\text { Apple }\end{array}$ & $\begin{array}{l}\text { Malus domestica Borkh. } \\
\text { ROSACEAE }\end{array}$ & 11 & {$[11]$} \\
\hline $\begin{array}{l}\text { Laranja amarga } \\
\text { Sour Oranges }\end{array}$ & $\begin{array}{l}\text { Citrus aurantiifolia (Christm.) Swingle } \\
\text { RUTACEAE }\end{array}$ & 10 & {$[9],[10]$} \\
\hline $\begin{array}{l}\text { Batata-Doce } \\
\text { Sweet Potato }\end{array}$ & $\begin{array}{l}\text { Ipomoea batatas (L.) Lam. } \\
\text { CONVOLVULACEAE }\end{array}$ & 9 & - \\
\hline $\begin{array}{l}\text { Cacau } \\
\text { Cocoa }\end{array}$ & $\begin{array}{l}\text { Theobroma cacao L. } \\
\text { MALVACEAE }\end{array}$ & 9 & {$[11]$} \\
\hline $\begin{array}{l}\text { Uva } \\
\text { Grapes }\end{array}$ & $\begin{array}{l}\text { Vitis vinifera L. } \\
\text { VITACEAE }\end{array}$ & 9 & [7]-[11] \\
\hline $\begin{array}{l}\text { Castanha do Pará } \\
\text { Brazil Nut }\end{array}$ & $\begin{array}{l}\text { Bertholletia excelsa Bonpl. } \\
\text { LECYTHIDACEAE }\end{array}$ & 9 & - \\
\hline $\begin{array}{l}\text { Goiaba } \\
\text { Guava }\end{array}$ & $\begin{array}{l}\text { Psidium guajava L. } \\
\text { MYRTACEAE }\end{array}$ & 9 & {$[11]$} \\
\hline $\begin{array}{l}\text { Limão } \\
\text { Lemon }\end{array}$ & $\begin{array}{l}\text { Citrus limon (L.) Osbeck } \\
\text { RUTACEAE }\end{array}$ & 9 & {$[9],[10]$} \\
\hline
\end{tabular}

\subsection{Top-ranking spices grown and traded now and in the 16 th and 17 th centuries}

The 2019/2020 survey recorded 17 plant species used as spices. Top-ranking chilli peppers are a must in Recife's kitchens, as well as garlic, with 11 occurrences. Both became essential from the early years of Portuguese colonisation, and Pernambucanos have, again, the habit of preserving Chilli peppers in cachaça (a sugarcane alcoholic drink). Fig. 6 displays several of those bottles, sold in a central Recife shop. The next photo shows the historic square of the capital of Pernambuco, a city founded in 1630 by the Dutch, along the rivers Beberibe and Capibaribe. Fig. 7 displays the port area where Recife agglomeration started, during their short domain. It is the trade area, where the Jews still conduct their business, and where several administration services are located. Museums are also abundant in the 


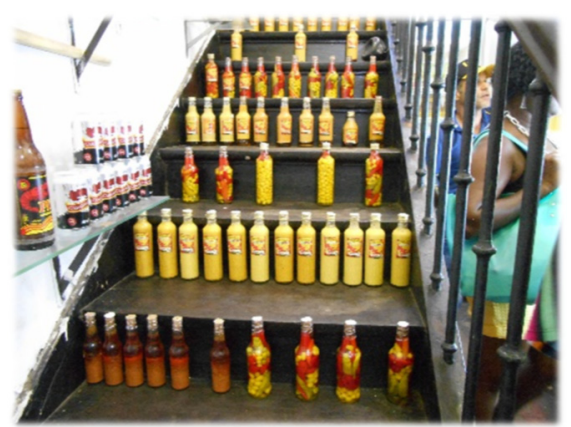

Figure 6: Chilli peppers and all sorts of fruits are mixed with cachaça. (Source: Author's photo, 2019.)

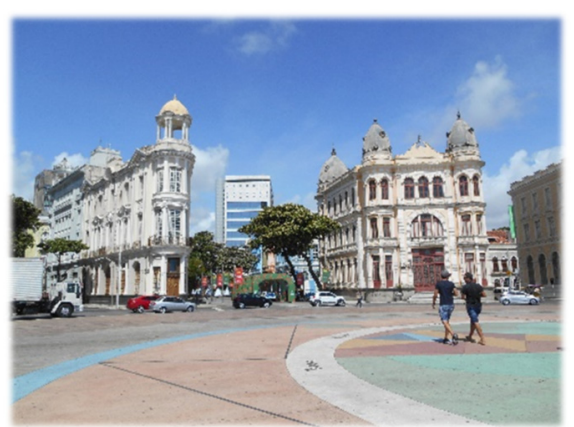

Figure 7: Central Recife neighbourhood. (Source: Author's photo, 2019.)

Table 2: Top-ranking spices traded and grown in Recife, in the old times and today. (Source: Author, 2020.)

\begin{tabular}{|l|l|c|c|}
\hline $\begin{array}{l}\text { Common names } \\
(\text { in English })\end{array}$ & Botanical names & $\begin{array}{c}\text { Occurrences } \\
(\mathrm{n} .)\end{array}$ & $\begin{array}{c}\text { Manuscripts } \\
\text { mentioned }\end{array}$ \\
\hline $\begin{array}{l}\text { Pimentinha } \\
\text { Chilli pepper }\end{array}$ & $\begin{array}{l}\text { Capsicum annuum L. } \\
\text { SOLANACEAE }\end{array}$ & 12 & {$[9],[10]$} \\
\hline $\begin{array}{l}\text { Alho } \\
\text { Garlic }\end{array}$ & $\begin{array}{l}\text { Allium sativum L. } \\
\text { AMARYLLIDACEAE }\end{array}$ & 11 & {$[8],[11]$} \\
\hline $\begin{array}{l}\text { Canela } \\
\text { Cinnamom }\end{array}$ & $\begin{array}{l}\text { Cinnamomum zeylanicum Blume } \\
\text { LAURACEAE }\end{array}$ & 10 & {$[7],[8],[11]$} \\
\hline $\begin{array}{l}\text { Salsa } \\
\text { Parsley }\end{array}$ & $\begin{array}{l}\text { Petroselinum crispum } \text { (Mill.) Fuss. } \\
\text { APIACEAE }\end{array}$ & 6 & {$[9],[10]$} \\
\hline $\begin{array}{l}\text { Cravinho } \\
\text { Clove }\end{array}$ & $\begin{array}{l}\text { Syzygium aromaticum } \text { (L.) Merr. and } \\
\text { L.M. Perry } \\
\text { MYRTACEAE }\end{array}$ & 5 & {$[11]$} \\
\hline $\begin{array}{l}\text { Pimenta do Reino } \\
\text { Indian Pepper }\end{array}$ & $\begin{array}{l}\text { Piper nigrum L. } \\
\text { PIPERACEAE }\end{array}$ & 4 & {$[8],[11]$} \\
\hline $\begin{array}{l}\text { Orégãos } \\
\text { Marjoram }\end{array}$ & $\begin{array}{l}\text { Origanum vulgare L. } \\
\text { LAMIACEAE }\end{array}$ & 4 & - \\
\hline
\end{tabular}

neighbourhood, most of them devoted to Carnival costumes. The so-called frevo is Recife's most appreciated dance, associated to that festive season. Street grid is usually regular, very different from the irregular shape of Olinda, above the Portuguese hills.

Going back to our spices, garlic has anti-oxidant effects, its consumption improves memory and learning capabilities [15]. Next, in Table 2 is cinnamon, imported from Ceylon, during the colonisation era. It became important for bakery, and unlike the Indian pepper, cinnamon trees could be freely planted in the home gardens and farms, as it was not a royal monopoly. The curiosity is clove; botanists consider it to be endemic in Extreme Orient Islands, as the Moluccas, but modern research tends to point otherwise. In fact, when reading 
Father Vieira we realise the Jesuits had clove collected from the wild by the Indians [11]. Saragoça, a Brazilian researcher, claims that the species is spontaneous in Amazonia, even though the bark was used instead of the flower [16].

\subsection{The natural remedies used in Recife}

About $80 \%$ of the world population uses medicinal plant species [17]. In Recife we found 84 $(43.8 \%)$ taxa with curative and cosmetic usages. The highest proportion of plant portions, leaves, stems and flowers, could be seen in the markets, supermarkets, and pharmacies devoted to the trade of natural products and food supplements. In the gardens, biodiversity was considerable, fruit trees like banana, mango, papaya and coconut palms were mixed with fake boldus and peppermint (Figs 8 and 9). Whereas fake boldus, common in Northern Brazilian gardens, as recorded in St. Louis [18], is consumed against diarrhoea, indigestion and belly aches, peppermint is taken in syrups made of sugar, cinnamon and Mentha piperita leaves. This anti-cough prescription was recommended by an over 80 year old lady, a transgenerational heritage that is part of Brazilian culture. Peppermint was mentioned in Vieira writings [11].

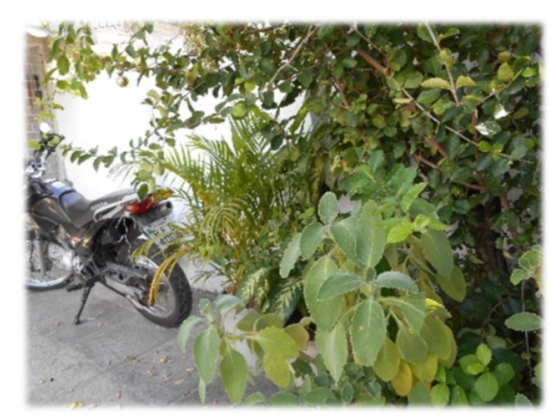

Figure 8: Fake boldus from a garden. (Source: Author's photo, 2020.)

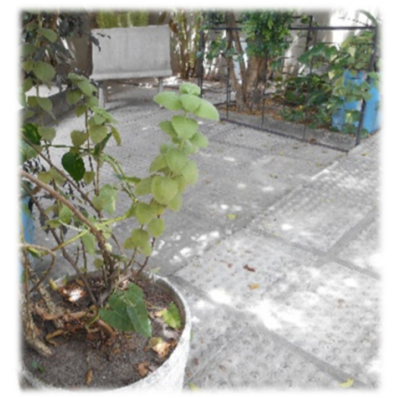

Figure 9: Peppermint from Recife. (Source: Author's photo, 2020.)

Chamomile is the top-ranking medicinal herb consumed in Recife, selected for its sedative effects as was the case with Lima, Peru and San José, Costa Rica, in previous research missions [19]. Green tea had 12 records, because of its consumption for weight loss. As to black tea it had six occurrences, which number added to the previous, totalling 18 preferences for Thea sinensis (Table 3). Fennel goes third and it is frequently used to make soaps and creams, some of them manufactured in Recife, alone or combined with sweet almonds and scented jasmine flowers. It is also consumed in teas as it is recommended as digestive. The same prescription is applied to Chilean boldus or real boldus (Peumus boldus), carqueja (eight records), citronelle (13), and Lavandula angustifolia flowers (five occurrences). Fennel is ingredient for banana cakes, the best natural prescription against flatulence and diarrhoea.

Ginger, together with lemon gives anti-flu infusions. Hibiscus flowers are consumed against constipation, liver affections, cough and are anti-hypertensive. Hibiscus flowers are added to ginger, apple, cinnamon, clove and other spices in digestive infusions, highly 
Table 3: Top-ranking medicinal plant species traded and grown in Recife. (Source: Author, 2020.)

\begin{tabular}{|c|c|c|c|}
\hline $\begin{array}{l}\text { Common names } \\
\text { (in English) }\end{array}$ & Botanical names & $\begin{array}{l}\text { Occurrences } \\
\text { (n.) }\end{array}$ & $\begin{array}{c}\text { Manuscripts } \\
\text { mentioned }\end{array}$ \\
\hline $\begin{array}{l}\text { Camomila } \\
\text { Chamomille }\end{array}$ & $\begin{array}{l}\text { Matricharia chamomilla } \mathrm{L} . \\
\text { ASTERACEAE }\end{array}$ & 18 & - \\
\hline $\begin{array}{l}\text { Chá verde e preto } \\
\text { Green, black teas }\end{array}$ & $\begin{array}{l}\text { Thea sinensis L. } \\
\text { THEACEAE }\end{array}$ & 18 & - \\
\hline $\begin{array}{l}\text { Erva-Doce } \\
\text { Fennel }\end{array}$ & $\begin{array}{l}\text { Foeniculum vulgare L. } \\
\text { APIACEAE }\end{array}$ & 16 & - \\
\hline $\begin{array}{l}\text { Gengibre } \\
\text { Ginger }\end{array}$ & $\begin{array}{l}\text { Zingiber officinalis L. } \\
\text { POACEAE }\end{array}$ & 14 & {$[8]-[11]$} \\
\hline $\begin{array}{l}\text { Capim Cidreira } \\
\text { Citronnelle }\end{array}$ & $\begin{array}{l}\text { Cymbopogon citratus (DC.) Stapf } \\
\text { SOLANACEAE }\end{array}$ & 13 & - \\
\hline $\begin{array}{l}\text { Hibisco } \\
\text { Hibiscus }\end{array}$ & $\begin{array}{l}\text { Hibiscus sabdariffa L. } \\
\text { MALVACEAE }\end{array}$ & 10 & - \\
\hline $\begin{array}{l}\text { Ameixa } \\
\text { Prune }\end{array}$ & $\begin{array}{l}\text { Prunus domestica L. } \\
\text { ROSACEAE }\end{array}$ & 9 & - \\
\hline $\begin{array}{l}\text { Hortelã } \\
\text { Peppermint }\end{array}$ & $\begin{array}{l}\text { Mentha piperita } \mathrm{L} . \\
\text { LAMIACEAE }\end{array}$ & 8 & [11] \\
\hline $\begin{array}{l}\text { Amêndoa } \\
\text { Almond }\end{array}$ & $\begin{array}{l}\text { Prunus dulcis (Mill.) D.A. Webb } \\
\text { ROSACEAE }\end{array}$ & 8 & - \\
\hline Carqueja & $\begin{array}{l}\text { Baccharis gaudichaudiana DC., } B . \\
\text { trimera (Less) DC. } \\
\text { ASTERACEAE }\end{array}$ & 8 & - \\
\hline $\begin{array}{l}\text { Chá-Mate } \\
\text { Mate tea }\end{array}$ & $\begin{array}{l}\text { Ilex paraguariensis A. St.-Hil. } \\
\text { AQUIFOLIACEAE }\end{array}$ & 8 & - \\
\hline
\end{tabular}

appreciated in Recife. Ginger is consumed as spice, either, and it was mentioned in old manuscripts. Another exotic species, brought by the Portuguese is rosemary, elected for New Year in flowered gifts, because it brings money and thus gives good luck. In Recife, rosemary is, together with rue, and several native aromatic species, used in baths and superstitious applications.

It was a surprise to record how many different tea brands there are in Recife's markets and supermarkets, where mate has an important role. Usually associated to southern Brazilian states, and to Uruguay, Argentina or Paraguay, Ilex paraguariensis had eight records [20]. The main cosmetic preferences are prunes, sweet almonds, roses, rosemary, coconuts, jasmine and aloe, applied for body and hair care. The seed of the native Amazon palm Astrocaryum murumuru is frequently used to manufacture shampoos, as the oil is ingredient for local industries.

\subsection{The vulnerable species in Recife}

Two plant species are in vulnerable status: (1) Brazil-wood, depredated from the Atlantic forests in the early years of colonisation; (2) Coroa de Frade, a cactus (Melocactus ernestii) used as anti-helminthic. The first was mentioned in de Anchieta [10] and Vieira writings [11], but in our days the tree can only be found in the Botanical gardens of Recife (Fig. 10). There 
is hope, however, because botanists keep a nursery there, in order to replant the trees of Caesalpinia echinata in the remainder forests or Mata Atlântica. As to the cactus, it is sold in the markets, as recorded in S. José, but it is an illegal practise. The healing properties make the cactus valuable in traditional medicinal practises, as they extract the spines to consume it against intestinal worms. The species formerly grew wild in dry interior areas, called caatinga, but now is in the red list, because of the continuous depredation it suffers from wild plant collectors (Fig. 11). The trade is forbidden. The caatinga occupies $11 \%$ of Brazil, including Pernambuco State, and has high economic potential and is very biodiverse [21].

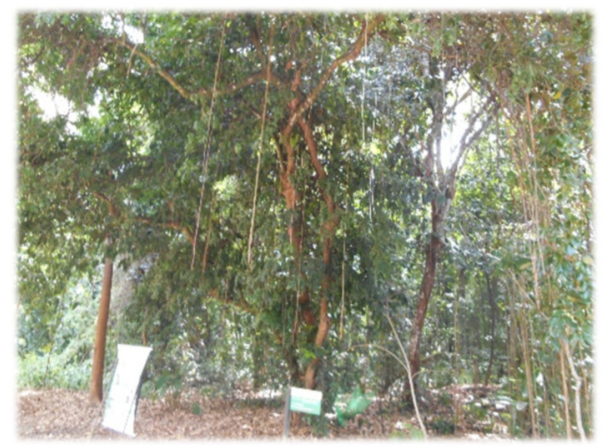

Figure 10: Brazil-wood, the Mata Atlântica tree, exploited to near extinction during colonization. (Source: Author's photo, 2020.)

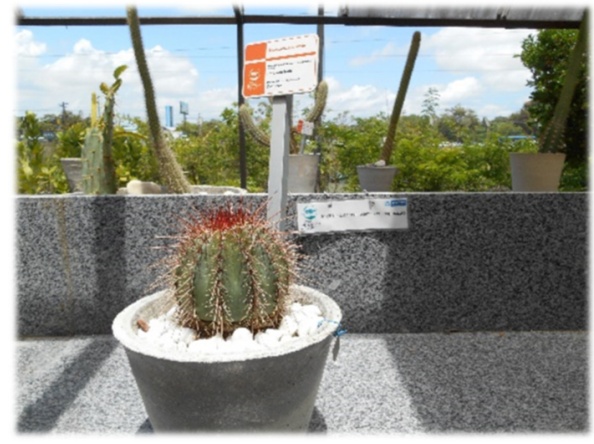

Figure 11: Coroa de Frade, from the arid interior areas of Pernambuco, caatinga. (Source: Author's photo, 2020.)

\section{URBAN GROWTH OF RECIFE}

The city of Recife has 94 neighbourhoods spread from the river Beberibe, on the border limit with Olinda municipality, the first settlement from 1537, and the southern municipalities of Jaboatão and Guararapes (see detailed map in Fig. 2) Other couple of rivers cut Recife's urban agglomeration - the Capibaribe and the Tejipió - giving the city the label of tropical Venice. Recife grew through times, in three areas: (1) The port area, protected by a fort from the 16th century; (2) The island of António Vaz, dominated by sugarcane plantations, by the end of the 16th century and beginning of the 17th; and (3) Boa Vista neighbourhood, which urbanisation dates from the 18th century onwards [22]. The church of Our Lady of the Good Travels (Boa Viagem) was erected those days, either, in 1707, and it now marks the beginning of the urbanisation of the fourth nucleus, the southern touristic area of beaches (see photo in Fig. 12 and detail map in Fig. 2).

As said, the beginning of Portuguese colonisation started with Olinda agglomeration, on the Northern hills (Fig. 13). The communication of Olinda with the sugarcane plantations located in António Vaz Island, was done by boat. Only in 1644 the Dutch built a bridge. In fact, Dutch colonisers arrived in 1630, burnt down the whole Olinda settlement and forced the Portuguese to come down the hills to the low-lying areas, as they were used to do back in The Netherlands. They created a new settlement called Maurisstadt, after the name of the Count of Nassau, in 1630. A 1645 census informs that the now called Recife accounted for 8,000 people [22]. 


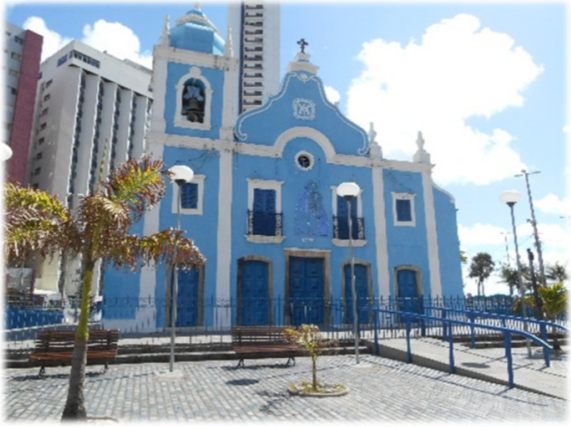

Figure 12: The Church of Boa Viagem. (Source: Author's photo, 2019.)

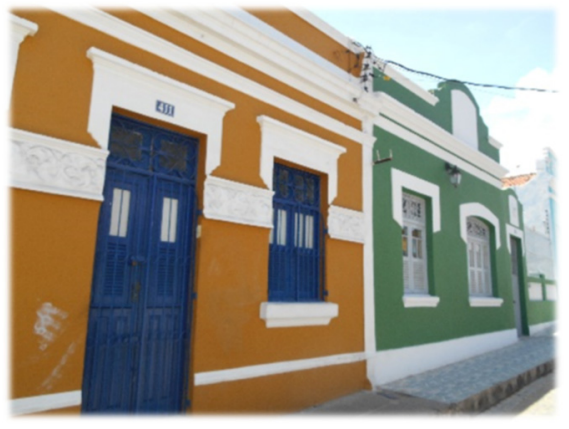

Figure 13: Olinda, the Portuguese city. (Source: Author's photo, 2019.)

The Dutch occupation only lasted 24 years, from 1630 to 1654 . In 1823, following the independence declaration of Brazil from Portugal (1822), Recife became city. In 1827, it became officially the capital of the State of Pernambuco. It is now a regional metropolis that aggregates 13 municipalities, including Olinda. It is one of the richest in the North-eastern Region of the country, possessing high skyscrapers, and it is an important technological and industrial pole. The actual urban planning work dates from 1907, but only after 1950, the touristic Boa Viagem neighbourhood was developed [22]. The municipality of Recife accounts for over one million and a half residents [23].

\section{CONCLUSIONS}

So, was flora consumption sustainable in Recife, from the beginning of Portuguese colonisation to our days? The answer to the research question is yes, with the exception of Brazil-wood, exploited in the first economic cycle to near depredation. Sugarcane plantations required heavy workforce and so slavery was essential to develop the second economic cycle of colonisation. With the union of the Portuguese and the Spanish kingdoms, between 1580 and 1640, Dutch occupation followed suit, giving way to the edification of a new settlement in low-lying areas (1630-1654), called Recife, after the reefs from the Atlantic shores. This agglomeration grew southwards and inwards. Consequently, the Atlantic forests (Mata Atlâtica) shrank and sugar plantations were replaced by modern fruit farms, settled further inland. Recife still has shady and biodiverse gardens; however, skyscrapers dominate the city now, as industry, trade and services replaced former farming cycle.

\section{ACKNOWLEDGEMENT}

Thanks are due to all informants for their availability to share food habits and medicinal remedy applications, during the scientific mission to Recife, Brazil.

\section{REFERENCES}

[1] McDonald, R.I. et al., Research gaps in knowledge of the impact of urban growth in biodiversity. Nature Sustainability, 3, pp. 16-24, 2019.

DOI: 10.1038/s41893-019-0436-6.

[2] Applequist, W.L. et al., Scientists warning on climate change and medicinal plants. Planta Med, 86(1), pp. 10-18, 2019. 
[3] da Costa, B.B.F. \& Motta, A.L.T.S., Key factors hindering sustainable procurement in the Brazilian public sector: A delphi study. International Journal of Development and Planning, 14(2), p. 152, 2019.

[4] Cidade Brazil, Recife data. www.cidade-brasil.com.br/municipio-recife.html. Accessed on: 26 Feb. 2020.

[5] Climate data, Recife weather. https://pt.climate-data.org/america-do-sul/brasil/ pernambuco/recife-5069/\#climate-graph. Accessed on: 26 Feb. 2020.

[6] Cavalcanti, V.B., Olinda do Salvador do Mundo: biografia de uma cidade, Companhia Editora de Pernambuco: Recife, 2017.

[7] de Goes, D., Chronica do Sereníssimo Rey D. Emanuel, Reinerio Bocache, Officina de Miguel Manescal da Costa: Lisbon, 1749.

[8] de Castanheda, F.L., Historia do Descobrimento e Conquista da Índia pelos Portugueses, João Barreira \& João Alvarez, 1552-1561: Coimbra. http://purl.pt/15294. Accessed on: 16 Feb. 2016.

[9] de Anchieta, J., Relação da Província do Brazil. Vitae Padre Joseph Anchieta, Manuscrito Vitae 153, Archivum Romanum Societatis Iesu, eds R. Petrus, V. Simon \& S. Beretario, pp. 54-66, 1610.

[10] de Anchieta, J., Cartas, Informações, Fragmentos Históricos e Sermões: 1554-1594, Civilização Brasileira: Rio de Janeiro, 1933.

[11] Franco, J.E. \& Calafate, P., Obra Completa Padre António Vieira, Círculo de Leitores: Lisbon, 2013-2014.

[12] MBG, Plant Identification, Missouri Botanical Garden. www.tropicos.org. Accessed on: 26 Feb. 2020.

[13] Ong, W.T. \& Ong, A.L.R., Stay Younger, Live Healthier, Aris Printhaus: Manila, 2014.

[14] Madaleno, I.M., Landscapes of health: The Kochi case-study. Sustainable City IX. Urban Regeneration and Sustainability, eds N. Marchettini, C.A. Brebbia, R. Pulselli \& S. Bastianoni, WIT Press: Southampton and Boston, pp. 1709-1720, 2014.

[15] Madaleno-Ferreira, D., A Importância da Alimentação na Doença de Alzheimer. Unpublished Master's thesis, Faculdade de Farmácia da Universidade de Lisboa, Lisbon 2019.

[16] Saragoça, L., A Amazónia vista por dentro. Do Ciclo das Drogas do Sertão ao Ciclo da Agricultura. Viagens no Interior do Brasil, ed. F. Cristóvão, Centro de Literaturas e Culturas Lusófonas e Europeias: Lisbon, pp. 81-127, 2014.

[17] Trigueros-Vázquez, I.Y., German, B.G., Victoria, C.R. \& Sánchez, A.I.G., Uso de plantas medicinales en Paso Serrano, Manlio Fabio Altamirano, Veracruz: Un estudio de caso, 2018. www.researchgate.net/publication/331859439. Accessed on: 19 Mar. 2019.

[18] Madaleno, I.M., Plantas da medicina popular de São Luís, Brasil. Boletim do Museu Paraense Emílio Goeldi. Ciências Humanas, 6(2), pp. 273-286, 2011.

[19] Madaleno, I.M., Estudo Etnogeográfico de Plantas Medicinais da América Latina, Alêtheia Editores: Lisbon, 2013.

[20] Madaleno, I.M. \& Montero, M.C., El cultivo urbano de plantas medicinales, su comercialización y usos fitoterapéuticos en la Ciudad de Río Cuarto, Provincia de Córdoba, Argentina. Cuadernos Geográficos, 50(1), pp. 63-85, 2012.

[21] Ministry of the Environment, Caatinga. www.mma.gov.br/biomas/caatinga. Accessed on: 28 Feb. 2020.

[22] Cavalcanti, V.B., O Recife e seus bairros, Poço Cultural: Recife, 2016.

[23] Fonseca, H., Pernambucânia, Companhia Editora de Pernambuco: Recife, 2018. 